\title{
THE EFFECT OF TECHNOLOGICAL COMPLEXITY (KT) AND COMPATIBILITY (KOM) ON THE SUSTAINABILITY OF THE GREEN AND SMART PORT CONCEPT (CTU): TAM EXTENDED APPROACH CASE STUDY AT TELUK LAMONG TERMINAL, A SUBSIDIARY OF PT PELINDO III
}

\author{
Reka Yusmara Mardiputra ${ }^{1 *}$, Kusuma Ratnawati', Ananda Sabil $\mathbf{H}^{1}$ \\ 'School of Management, Economic and Business Faculty, Brawijaya University \\ Address: ' Jl. MT. Haryono 165, Lowokwaru, Malang, Indonesia 65145 \\ *Email : reka.mardiputra@gmail.com
}

\begin{abstract}
This study examines and analyzes the relationship between the technological complexity (KT) and compatibility (KOM), to a continuance to use (CTU) of green and smart port concepts using TAM theory extended. Adding technological complexity and compatibility as an external factor into TAM in terms of perceived usefulness (PU) and perceived ease of use (PEOU) that affect continuance to use green and smart concepts. This study uses a survey method. It is distributed to owners/operational/invoicing managers of Terminal Teluk Lamong (TTL) Customers (Shipping Company, Forwarding, Trucking Company) in Surabaya, Indonesia. The sampling technique is using Slovin's formula with 304 respondents. The data analysis technique uses SEM (Structural Equation Modelling) with SMART PLS 3.0. Both KT and KOM have a significant effect on PU and PEOU. Both PU and PEOU have a significant effect on CTU, and PEOU has a significant effect on PU. This research was conducted at TTL, the only terminal in Indonesia that uses the green and smart port concept. There is no comparison with other terminals in Indonesia on the implementation of the green and smart port concept. Especially for shipping companies, respondents cannot reach owner/principal/shareholders due to Indonesian government policy that international Shipping Companies are not allowed to open branches independently. However, they have to cooperate with local companies (agents). Port Industries (TTL) can develop an appropriate marketing strategy based on this research's results. Technological complexity and compatibility have a significant effect on the continuance to use GSP. Management of TTL has to consider technology and operational systems development with a low-level complexity and according to customer's needs. This research contributes to enrichment and extending TAM theory in terms of green and smart port concept sustainability. Not only affected by PU and PEOU but technological complexity (KT) and Compatibility (KOM) factors are important.
\end{abstract}

Keywords: Green and Smart Port (GSP), Technology Complexity (KT), Compatibility (KOM), TAM (Technology Acceptance Model), Continuance to Use (CTU)

JEL Classification: $\mathrm{L} 26, \mathrm{O} 14, \mathrm{O} 32$

Article History:

Received: June 22, 2021; Revised: August 12, 2021; Accepted: August 16, 2021; Available Online : August 28, 2021 DOI: $10.20473 / \mathrm{jm} t$ t.v14i2.27668

\section{INTRODUCTION}

The construction and development of ports in Indonesia have enhanced the port industry's competition in the last ten years. At least there are eight ports which under construction and development in Indonesia since 2014. Competition has increased to a port operated by stateowned companies and to private port operators. The keyword in winning a competition is customer loyalty. Customer loyalty's dimension: first, recommendation, a loyal customer would 


\section{Reka Yusmara Mardiputra \\ Kusuma Ratnawati \\ Ananda Sabil H}

recommend other people around them about the company. Second, loyal customers would make a repeat purchase of the products or services they trust (Yang and Petterson, 2016). The bigger the loyal customers, as bigger the chance to win the market. PT Pelindo III (Persero) has made innovations in port development in its working area by building a port with a green and smart concept. It is named Terminal TelukLamong (TTL). TTL is the first green and smart port in Indonesia.

The green and smart concept is a value proposition for TTL, which is expected to increase customer loyalty. The smart concept at TTL provides online transactions 24 hours 7 days based on information technology. Then, the crane equipment used is based on automation and is powered by electricity. The environment around TelukLamong port is beautiful, with various plants in the terminal area. The environment around the terminal is maintained in terms of air, air, and ground. However, this green and smart port concept are the first in Indonesia, so customers need to adapt the technologies and systems implemented in the green and smart port concept.

The theory of TAM (Technology Acceptance Model) was first introduced by Davis (1989). It was mentioned in various previous studies that it could be used to determine a person's attitude, interest, or behavior in adopting technology. The variables used are perceived usefulness (PU) and perceived ease of use (PEOU) which can affect an intention to use or continuance to use. A previous study by C. Lisa et al. (2017) had stated in their study that perceived usefulness (PU) and perceived ease of use (PEOU) have a significant effect on continuance intention to use the chatbot. Terminal TelukLamong, (TTL), a modern port based on ICT systems and equipment that is automated and environmentally friendly. TAM theory has not fully answered the influence of PU and PEOU variables on a person's attitude to continue using the green smart port concept. The level of technological complexity used in implementing the green smart port is seen by researchers as a factor to be considered in transacting at TelukLamong Terminal. Likewise, with environmentally friendly policies, researchers assume that green policies can influence service users to consider transacting in TTL or not. This relates to the compatibility of a system or technology to its customers, seen from the extent to which technology or system is under the needs of customers

Chin and Lin (2015), in their research, stated that compatibility (C) and technological complexity (TC) support the research results and become an important consideration in the acceptance of BEMS (Building Energy Management System) technology. C and TC variables are placed as an extension of the TAM theory to complement the influence of PU and PEOU on an intention or continuance to use. This study would fill the TAM Theory gap on green and smart port implementation. For that reason, this study added the variables of technological complexity (KT) 
and compatibility (KOM) to the PU and PEOU variables on the continuance to use (CTU) green and smart port concept.

\section{LITERATURE REVIEW AND HYPOTHESES}

Technological Complexity (KT), Compatibility (KOM), Perceived Usefulness (PU), and Perceived

\section{Ease of Use (PEOU)}

Complexity, according to KBBI (Big Indonesian Dictionary), is intricacy. Complexity is the level of innovation that is perceived as relatively difficult to understand and use. About technological complexity, it can be interpreted as the level of innovation of new technology or system, which brings new elements resulting in simplicity, unusualness, and abnormality in the application of a technology or system (ww.academia.edv, 2019). In implementing green and smart ports, the complexity of the technology used includes automation and electricity-fueled equipment technology. In addition, transactions are carried out online 24 hours 7 days using applications based on information communication technology (ICT). The operating system in TTL has become more complex than the operational system in conventional terminals. In several previous studies, although with different research objects, it was found that technological complexity affects perceived usefulness (PU) and perceived ease of use (PEOU) (Chin and Lin, 2015; Somang, Kevin and Miyoung, 2019; B.A Akinnuwesi et al., 2016)

\section{$\mathrm{H}_{1}$ : Technological Complexity has an effect on Perceived Usefulness (PU) \\ $\mathrm{H}_{2}$ : Technological Complexity has an effect on Perceived Ease of Use (PEOU)}

Compatibility in language can be interpreted as conformity (KBBI). Suppose it is associated with a technology or system. In that case, the compatibility of a system or technology is the condition of existing facilities or resources compared to the new technology or system. With the greater deviation value of a system compared to existing facilities and resources, the system will certainly have difficulty being accepted by customers. Rogers (Mazhar, 2014) defines compatibility as the level of consistency between technology and new customer needs, daily life routines, experiences, and values. Compatibility also relates to individual lifestyle and technology. Several studies (Somang, Kevin, and Miyoung, 2019; Chin and Lin, 2015; Di Pietro et al., 2015; Shakrokh, 2019) state that compatibility significantly affects perceived usefulness and perceived ease of use. Although Di Pietro et al., 2015 did not place the technological complexity variable and only had a significant effect on PU. Meanwhile, Shakrokh, 2019 states that compatibility has a significant effect on PU and PEOU

\section{$\mathrm{H}_{3}$ : Compatibility has an effect on Perceived Usefulness (PU) \\ $\mathrm{H}_{4}$ : Compatibility has an effect on Perceived Ease of Use (PEOU)}




\section{Reka Yusmara Mardiputra \\ Kusuma Ratnawati \\ Ananda Sabil H}

\section{Perceived Usefulness (PU), Perceived Ease of Use (PEOU) and Continuance to Use (CTU) - TAM}

\section{Theory}

According to Venkatesh and Davis in (Devi and Suartana, 2014), perceived usefulness is a level of individual belief that using the system or technology can improve performance. Weng et al., 2017 in their research, stated that perceived usefulness (PU) has a significant effect on continuance intention to use Mobile Taxi Booking Application Service, and perceived ease of use (PEOU) had a significant effect on PU. Likewise, Lisa et al., 2017 mention in their study that perceived ease of use (PEOU) have a significant effect on perceived usefulness (PU). PU has a significant effect on a continuance to use the WeChat application. The TAM theory has stated that a person will judge the usefulness and ease of using a new technology or system in adopting a technology or system. This is supported by several previous studies that have been mentioned above

According to a study by Ramayah and Ignatius, 2006 which includes dimensions of perceived usefulness are (1) Effectiveness is a perception that shows the time savings from using technology or system. (2) Accomplish faster is a dimension that describes the extent to which a job can be done more quickly by using a system or technology. (3) Useful is dimensions that describe the extent to which technology or system can be helpful for someone, especially in company activities. (4) Advantageous is dimensions that describe the benefits of using a system or technology

While perceived ease of use, according to Dewi et al., 2013 is "a belief that using technology will be effortless." It can be interpreted that perceived ease of use is a person's level of confidence in using a system or technology that impacts ease of work.

According to a study by Ramayah and Ignatius, 2006 which includes the dimensions of perceived ease of use are (1) Easiness is the ease of a system or technology to use. (2) Clear and Understandable is the extent to which the system or technology used is clear and easy to understand. (3) Easy to Learn is the degree of ease of a system or technology for someone to learn or adopt. (4) Overall Easiness is the overall level of ease of a system or technology used

From the several previous studies mentioned above, the existence of the PU and PEOU variables is important as a factor that affects an intention and continuance intention to use (Lisa et al., 2017; Weng et al., 2017; Taufik and Hanafiah, 2019; Wu and Chen, 2016; Ho et al., 2020; Cheng Y.M., 2015; Ashfaq et al., 2020; Coordinate et al., 2019; Hamid et al., 2016)

\section{$\mathrm{H}_{5}$ : Perceived Usefulness (PU) has an effect on Continuance to Use (CTU) \\ H6: Perceived Ease of Use (PEOU) has an effect on Continuance to Use (CTU) \\ $\mathrm{H}_{7}$ : Perceived Ease of Use (PEOU) has an effect on Perceived Usefulness (PU)}


Technological Complexity (KT), Compatibility (KOM), and Continuance to Use (CTU)

According to Davis in (Teng and Chen, 2010), continuance intention to use is the interest or desire of a person to continue using a system or technology. Meanwhile, according to Bhattacherjee in (Islam and Mantymaki, 2011), continuance intention to use can be interpreted as the interest of an individual to continue to participate or take part in a particular system.

As research conducted by Anderson and Sullivan in (Hung and Hsu, 2011), the dimensions of continuance intention to use are (1) Possibility of Repurchase is The probability that a person takes in using a system or technology again. (2) Times of Repurchase refers to an interest in using an online service system and the possibility of purchasing or transactions in an online system or technology

Previous research (Mndzebele, 2013; Chin and Lin, 2015; B.A Akinnuwesi et al., 2016; Shakrokh, 2019) states that the technological complexity and compatibility variables have a significant effect on a continuance to use a variable. Another study stated that the technological complexity variable had an indirect effect on a continuance to use (Somang, Kevin, and Miyoung, 2019). Technology complexity affects PU, and PU had an effect on a continuance to use. Meanwhile, the compatibility variable was found to have no effect on adopting the Integrated Model on Mobile Payment (IMMPA). However, it had an effect on PU, and PU had a significant effect on the adoption of IMMPA (Di Pietro et al., 2015).

\section{$\mathrm{H}_{8}$ : Technological Complexity (KT) has an effect on Continuance to Use (CTU) \\ Ha: Compatibility (KOM) has an effect on Continuance to Use (CTU) \\ $\mathrm{H}_{10}$ : Technological Complexity (KT) has an indirect effect on Continuance to Use (CTU) \\ $H_{11}$ : Compatibility (KOM) has an indirect effect on Continuance to Use (CTU)}

\section{RESEARCH METHOD}

This study was conducted by surveying the entire population of Terminal TelukLamong's customers (Shipping Company, Forwarder, and Trucking Company) in Surabaya, East Java, Indonesia. Port industries development in the last ten years has increased both ports under government and private sector. As Indonesia's first and one only green and smart port, TelukLamong Terminal (TTL) has a big challenge to gain market share. 2020 is the 5th (fifth) year the terminal has operated since it was inaugurated by the President of the Republic of Indonesia, Joko Widodo, in May 2015. When the research was conducted (2020), the data on the number of TTL customers taken as respondents reached 1,195. By using the Slovin formula, the total sample size is 300 respondents ( $\mathrm{n}$ $=\mathrm{N} /(1+\mathrm{Ne} 2)=1.195 /(1+1.195 \times 0.052)=299.8$ rounded to 300$)$. The sampling technique in this study used purposive sampling. The purposive sampling technique is a technique for determining samples for certain purposes only and is carried out based on certain criteria in the respondent (Sugiyono, 2014). All samples in this study are all TTL's customers with the criteria (1) Transactions 


\section{Reka Yusmara Mardiputra \\ Kusuma Ratnawati \\ Ananda Sabil H}

with TTL at least two times; (2) The minimum transaction is 100 boxes per year; (3) Still a registered customer in TTL's customer database. The type of data taken in this study is primary data, in questionnaires distributed to 304 respondents using google form media. Respondents included in the criteria are owner/CEO, operation manager, and invoicing manager from a shipping company, forwarding, or trucking company. All variables in this study used a Likert Scale measurement with a choice of number 1 (Strongly Disagree) to number 5 (Strongly Agree). They were testing the variables using validity and reliability tests. An explanation of the variables, operational definitions, and indicators in this study is shown in table 1.

Hypothesis testing in this study was carried out by (1) determining the significance level or critical value (alpha) of 5\%; (2) Comparing the t-statistic value with the t-table value. The t-table value for $5 \%$ alpha is 1.96 . So, the criteria for acceptance of the hypothesis when t-statistic $>t$-table ( $t$ statistic > 1.96).

Table 1.

Variables, Indicators, Items, and Source

\begin{tabular}{|c|c|c|c|}
\hline Variable & Indicators & Items & Source \\
\hline \multirow{2}{*}{$\begin{array}{l}\text { Technological } \\
\text { Complexity }\end{array}$} & $\begin{array}{l}\text { Technology or } \\
\text { Systems } \\
\text { Understanding }\end{array}$ & $\begin{array}{l}\text { 1. The Web access application for a } \\
\text { transaction is well understood } \\
\text { 2. Operational System (Automation) in TTL } \\
\text { is well understood }\end{array}$ & \multirow{2}{*}{$\begin{array}{l}\text { (Jacky Chin } \\
\text { and Shu- } \\
\text { ChiangLin, } \\
\text { 2015),(B.A } \\
\text { Akinnuwesiet } \\
\text { al., 2016) }\end{array}$} \\
\hline & $\begin{array}{l}\text { Technology or } \\
\text { System Difficulty } \\
\text { Level }\end{array}$ & $\begin{array}{l}\text { 3. I find it easy to use web access } \\
\text { application } \\
\text { 4. I find it easy to use operational facilities } \\
\text { and equipment (automation) at TTL }\end{array}$ & \\
\hline \multirow[b]{2}{*}{ Compatibility } & $\begin{array}{l}\text { Value of } \\
\text { Technology or } \\
\text { System }\end{array}$ & $\begin{array}{l}\text { 5. Web access application appropriate to } \\
\text { modern technology } \\
\text { 6. Online transaction } 24 / 7 \text { services at TTL } \\
\text { have added value } \\
\text { 7. Green terminal implementation at TTL } \\
\text { give added value }\end{array}$ & \multirow{2}{*}{$\begin{array}{l}\text { (Somang Min } \\
\text { et al., 2019), } \\
\text { (Otzurk et al., } \\
\text { 2016) }\end{array}$} \\
\hline & Customer's Need & $\begin{array}{l}\text { 8. Web access application and online } \\
\text { transaction } 24 / 7 \text { services at TTL } \\
\text { appropriate with customer's need } \\
\text { 9. Operational system (automation) at } \\
\text { TTL appropriate with customer's need } \\
\text { 10. Green terminal implementation at TTL } \\
\text { is appropriate with customer's need }\end{array}$ & \\
\hline \multirow[t]{2}{*}{$\begin{array}{l}\text { Perceived } \\
\text { Usefulness }\end{array}$} & Acceleration & $\begin{array}{l}\text { 11. Using web access application and } \\
\text { online transaction } 24 / 7 \text { services } \\
\text { accelerate my job } \\
\text { 12. TTL's operational automation system } \\
\text { accelerate my job at terminal } \\
\text { 13. TTL's green implementation accelerate } \\
\text { my job at terminal }\end{array}$ & \multirow[t]{2}{*}{$\begin{array}{l}\text { (Hyo-Jeong } \\
\text { Kim et al., } \\
\text { 2009),(Ramay } \\
\text { ahand } \\
\text { Ignatius., } \\
\text { 2006) }\end{array}$} \\
\hline & Usefulness & $\begin{array}{l}\text { 14. Using web access applications and } \\
\text { online transaction } 24 / 7 \text { services is }\end{array}$ & \\
\hline
\end{tabular}


useful for work and give benefit for my company

15. Operational automation system useful for work and give benefit for my company

16. TTL's Green implementation is useful for work and gives benefit for my company

17. Web access application is clear and the menus easy to understand

Understandable

18. The operational automation system TTL is clear, and the flow work is easy to

Perceived

Ease of Use understand

19. TTL's Green implementation has clear guidance and is easy to understand

(Dewi et al., 2013), (Ramay ahand

20. Web access application is easy to learn Ignatius, 2006)

21. Operational automation system TTL is easy to learn

22. TTL's Green implementation at TTL is easy to learn

23. Web access application and online transaction $24 / 7$ services will reuse for work and give benefit for my company

Re Purchase Possibility

24. Operational automation system TTL will reuse for work and give benefit for my company

25. TTL's Green implementation at TTL will reuse for work and give benefit for my company

26. I am interested and will continue to have transactions at TTL with an online transaction method

Online

Transaction
27. I will use TTL's transaction payment on the host to host platform at work and give benefit to my company

\section{RESULTS AND DISCUSSION Respondent's Description}

Based on the recapitulation of respondent data, 304 questionnaires have been distributed to international shipping companies (12 companies), domestic shipping companies (8 companies), EMKL/Forwarding companies (200 companies), and trucking companies (84 companies). A total of 304 questionnaires have been returned. 11 questionnaires do not meet the requirements of the respondents' criteria, so the respondent data that can be used are 293 questionnaires. Meanwhile, the classification of respondents based on the respondent's position in the company is divided into 6 (six) classifications, namely; Operations Manager 230 respondents (78.5\%), CEO 9 respondents (3.1\%), Branch Manager 20 respondents (6.9\%), Managing Director 1 respondent (0.2\%), Representative 4 respondents (1.4\%) and Export-Import Manager 29 respondents (9.9\%) 
Reka Yusmara Mardiputra

Kusuma Ratnawati

Ananda Sabil H

\section{Inferential Statistic Analysis}

This study uses inferential statistical analysis. This analysis is used to test the hypothesis and produce a model that is feasible (fit). Inferential statistical analysis is a statistical technique used to analyze sample data, and the results are applied to a clear population. The sampling technique from that population is done randomly. The data analysis method used Structural Equation Model (SEM) with the Partial Least Square (PLS) version 3.0 approach

\section{Outer Model Analysis}

The outer model analysis is carried out to ensure that the measurements used are feasible to be used as measurements or are valid and reliable. The outer model analysis specifies the relationship between latent variables and their indicators, or in other words, the outer model defines how each indicator relates to its latent indicators. The tests carried out on the outer model analysis include:

\section{Convergent Validity}

The value of convergent validity is the value of the loading factor on the latent variable with its indicators. The expected value is $>0.7$. The value of the outer model can still be tolerated up to 0.50 , and below the value of 0.50 , it must be eliminated from the analysis ( $\mathrm{H}$ Latan and Ghozali, 2015). The results showed that convergently, all of the data generated were valid. Although there are 4 (four) indicators with a value of less than 0.7 , it is already more than 0.5 , as shown in table 2.

Table 2.

Loading Factors Value

\begin{tabular}{|c|c|c|c|}
\hline \multicolumn{3}{|c|}{ Loading Factor } & \multirow{2}{*}{$\begin{array}{c}\text { Loading Factor } \\
0,937\end{array}$} \\
\hline $\mathrm{KTl} \leftarrow \mathrm{KT}$ & 0,973 & $\mathrm{PU} 1 \leftarrow \mathrm{PU}$ & \\
\hline $\mathrm{KT} 2 \leftarrow \mathrm{KT}$ & 0,948 & $\mathrm{PU} 2 \leftarrow \mathrm{PU}$ & 0,911 \\
\hline $\mathrm{KT} 3 \leftarrow \mathrm{KT}$ & 0,970 & $\mathrm{PU} 3 \leftarrow \mathrm{PU}$ & 0,693 \\
\hline $\mathrm{KT} 4 \leftarrow \mathrm{KT}$ & 0,968 & $\mathrm{PU} 4 \leftarrow \mathrm{PU}$ & 0,933 \\
\hline $\mathrm{KOMI} \leftarrow \mathrm{KOM}$ & 0,892 & PU5 $\leftarrow$ PU & 0,937 \\
\hline $\mathrm{KOM} 2 \leftarrow \mathrm{KOM}$ & 0,922 & $\mathrm{PU} 6 \leftarrow \mathrm{PU}$ & 0,687 \\
\hline $\mathrm{KOM} 3 \leftarrow \mathrm{KOM}$ & 0,735 & $\mathrm{PEOU} 1 \leftarrow \mathrm{PEOU}$ & 0,909 \\
\hline $\mathrm{KOM} 4 \leftarrow \mathrm{KOM}$ & 0,937 & $\mathrm{PEOU} 2 \leftarrow \mathrm{PEOU}$ & 0,911 \\
\hline $\mathrm{KOM} 5 \leftarrow \mathrm{KOM}$ & 0,916 & $\mathrm{PEOU} 3 \leftarrow \mathrm{PEOU}$ & 0,744 \\
\hline KOM $6 \leftarrow K O M$ & 0,685 & $\mathrm{PEOU} 4 \leftarrow \mathrm{PEOU}$ & 0,906 \\
\hline $\mathrm{PEOU} 5 \leftarrow \mathrm{PEOU}$ & 0,912 & CTU3 $\leftarrow$ CTU & 0,674 \\
\hline PEOU6 $\leftarrow$ PEOU & 0,753 & CTU4 $\leftarrow$ CTU & 0,969 \\
\hline CTU1 $\leftarrow$ CTU & 0,969 & CTU $5 \leftarrow$ CTU & 0,953 \\
\hline CTU2 $\leftarrow$ CTU & 0,957 & & \\
\hline
\end{tabular}

From the results of the analysis in table 2 above, there is a loading factor value that is $<0.7$ but $>$ 0.5 (KOM6, PU3, PU6, CTU3) so that all indicator data results in each (latent) variable are Convergently Valid. 


\section{Discriminant Validity}

The discriminant validity value is a cross-loading factor that is useful for determining whether the construct has an adequate discriminant by comparing the loading value. The intended construct must be greater than the value of loading another construct. The result of this study are shown in table 3 and table 4 below

Table 3.

Value of Discriminant Validity (Cross Loading)

\begin{tabular}{llllll}
\hline & CTU & KOM & KT & PEOU & PU \\
\hline KT1 & 0.809 & 0.816 & 0.973 & 0.599 & 0.762 \\
\hline KT2 & 0.784 & 0.821 & 0.948 & 0.593 & 0.775 \\
\hline KT3 & 0.790 & 0.804 & 0.970 & 0.606 & 0.761 \\
\hline KT4 & 0.788 & 0.813 & 0.968 & 0.573 & 0.756 \\
\hline KOM1 & 0.741 & 0.892 & 0.767 & 0.581 & 0.714 \\
\hline KOM2 & 0.822 & 0.922 & 0.799 & 0.599 & 0.762 \\
\hline KOM3 & 0.574 & 0.735 & 0.575 & 0.401 & 0.607 \\
\hline KOM4 & 0.818 & 0.937 & 0.810 & 0.648 & 0.819 \\
\hline KOM5 & 0.775 & 0.916 & 0.793 & 0.612 & 0.832 \\
\hline KOM6 & 0.517 & 0.685 & 0.513 & 0.437 & 0.535 \\
\hline PU1 & 0.790 & 0.821 & 0.776 & 0.607 & 0.937 \\
\hline PU2 & 0.748 & 0.771 & 0.727 & 0.598 & 0.911 \\
\hline PU3 & 0.521 & 0.561 & 0.463 & 0.524 & 0.693 \\
\hline PU4 & 0.766 & 0.790 & 0.765 & 0.591 & 0.933 \\
\hline PU5 & 0.794 & 0.812 & 0.782 & 0.585 & 0.937 \\
\hline PU6 & 0.508 & 0.517 & 0.467 & 0.486 & 0.687 \\
\hline PEOU1 & 0.617 & 0.619 & 0.573 & 0.909 & 0.586 \\
\hline PEOU2 & 0.617 & 0.569 & 0.539 & 0.911 & 0.587 \\
\hline PEOU3 & 0.471 & 0.511 & 0.458 & 0.744 & 0.507 \\
\hline PEOU4 & 0.584 & 0.582 & 0.564 & 0.906 & 0.585 \\
\hline PEOU5 & 0.600 & 0.555 & 0.548 & 0.912 & 0.609 \\
\hline PEOU6 & 0.465 & 0.502 & 0.475 & 0.753 & 0.515 \\
\hline CTU1 & 0.969 & 0.824 & 0.800 & 0.610 & 0.795 \\
\hline CTU2 & 0.957 & 0.780 & 0.755 & 0.590 & 0.760 \\
\hline CTU3 & 0.674 & 0.586 & 0.542 & 0.555 & 0.551 \\
\hline CTU4 & 0.969 & 0.822 & 0.797 & 0.620 & 0.806 \\
\hline CTU5 & 0.953 & 0.796 & 0.818 & 0.618 & 0.776 \\
\hline & & & & \\
\hline
\end{tabular}


Table 4.

Value of Discriminant Validity (Fornell-Larcker Criterion)

\begin{tabular}{lccccc}
\hline & CTU & KOM & KT & PEOU & PU \\
\hline CTU & 0.912 & & & & \\
\hline KOM & 0.841 & 0.854 & & & \\
\hline KT & 0.822 & 0.843 & 0.965 & & \\
\hline PEOU & 0.655 & 0.649 & 0.614 & 0.859 & 0.857 \\
\hline PU & 0.816 & 0.844 & 0.791 & 0.659 & \\
\hline
\end{tabular}

Data in table 4 shows that the value of the constructs intended for CTU, KOM, KT, PEOU, and PU is greater than the values for the other constructs (CTU-CTU > CTU-KOM; CTU-CTU > CTU-KT; CTU-CTU > CTU-PEOU; CTU-CTU > CTU-PU). Meanwhile, the AVE (Average Variant Extracted) values are all greater $(>$ ) than 0.5 (table 5)

\section{Reliability Testing uses Croanbach Alpha and Composite Reliability}

Cronbach Alpha strengthened reliability testing with an expected value $>0,6$ for all constructs. Meanwhile, composite reliability is shown with composite value $>0,7$. It is mean reliable usually if the composite reliability value bigger than Cronbach's alpha value.

Table 5.

Value of Cronbach's Apha, Composite Reliability, and AVE

\begin{tabular}{lccc}
\hline & Cronbach's Alpha & Composite Reliability & $\begin{array}{c}\text { AVE (Average Varian } \\
\text { Extracted) }\end{array}$ \\
\hline CTU & 0.945 & 0.960 & 0.831 \\
\hline KOM & 0.923 & 0.941 & 0.729 \\
\hline KT & 0.975 & 0.982 & 0.931 \\
\hline PEOU & 0.927 & 0.944 & 0.738 \\
\hline PU & 0.925 & 0.942 & 0.735 \\
\hline
\end{tabular}

Data in table 5 show that all constructs have Cronbach's alpha value bigger than (>) 0,6 and all composite reliability values shown bigger than (>) 0,7. The average Varian Extracted value is also shown as bigger than (>) 0.5 .

\section{Inner Model Analysis}

Inner model analysis or model structural analysis is carried out to ensure that the structural model built is strong and accurate. This analysis shows the relationship between the variables in accordance with the theoretical study and the results of previous studies. The evaluation of the inner model can be seen from several indicators, namely: 


\section{Coefficient of Determination (R2).}

The size of R2 shows the size of the influence of exogenous variables on endogenous variables. Exogenous variables are variables that affect other variables. At the same time, the endogenous variable is any variable that is influenced by other variables. If the value of $R 2$ is $0.75,0.50$, and 0.25 , it can be concluded that the model is strong, moderate, weak (H LatanandGhozali, 2012).

\section{Table 5.}

R Square

\begin{tabular}{lc}
\hline & R Square \\
\hline CTU & 0.779 \\
\hline PEOU & 0.437 \\
\hline PU & 0.749 \\
\hline
\end{tabular}

Data in table 5 shows that for the CTU and PU variables, the model can be concluded to be in a strong category, while PEOU, the model, is in the moderate category.

\section{The Goodness of Fit Index (GoF)}

The GoF coefficient has a value range of 0 to 1 . Getting closer to the value of 1 , the model shows a higher level of accuracy. Conversely, farther away from the value 1 or closer to the value 0 , the model shows a weaker level of accuracy. The criteria for the strength and weakness of the model are based on GoF measurements, namely 0.36 (GoF large); 0.25 (GoF medium); and 0.10 (GoF small) (Lathan andGhozali, 2012)

\section{Table 6.}

The goodness of Fit Index (GoF)

\begin{tabular}{lc}
\hline & $\begin{array}{c}\text { Saturated Model (Fit } \\
\text { Model) }\end{array}$ \\
\hline SRMR & 0.074 \\
\hline d_ULS & 2.063 \\
\hline d_G & 1.614 \\
\hline Chi-Square & 2331.918 \\
\hline NFI & 0.806 \\
\hline
\end{tabular}

Data in table 6 shows that the value of the NFI (Normal Fit Index) is 0.806 , where this value can be interpreted that the model proposed in this study is appropriate and good (the recommended value range is 0 to 1 ). 
Reka Yusmara Mardiputra

\section{Kusuma Ratnawati}

Ananda Sabil H

\section{Hypothesis Test}

The results of hypothesis testing in this study can be shown in table 7 and Figure 1.

Table 7.

The results of bootstrapping analysis in Smart PLS Version 3.0

\begin{tabular}{|c|c|c|c|c|c|}
\hline Hypothesis & $\begin{array}{l}\text { Original } \\
\text { Sample } \\
\text { (O) }\end{array}$ & $\begin{array}{c}\text { Sample } \\
\text { Mean (M) }\end{array}$ & $\begin{array}{l}\text { Standard } \\
\text { Deviaton } \\
\text { (STDEV) }\end{array}$ & t - Statistic & P Values \\
\hline $\mathrm{KT} \rightarrow \mathrm{PU}(\mathrm{Hl})$ & 0.239 & 0.225 & 0.110 & 2.170 & $0.031^{*}$ \\
\hline $\mathrm{KT} \rightarrow \mathrm{PEOU}(\mathrm{H} 2)$ & 0.232 & 0.229 & 0.107 & 2.165 & $0.031 *$ \\
\hline $\mathrm{KOM} \rightarrow \mathrm{PU}(\mathrm{H} 3)$ & 0.536 & 0.544 & 0.109 & 4.895 & $0.000 *$ \\
\hline $\mathrm{KOM} \rightarrow \mathrm{PEOU}(\mathrm{H} 4)$ & 0.454 & 0.440 & 0.113 & 4.021 & $0.000 *$ \\
\hline $\mathrm{PEOU} \rightarrow \mathrm{PU}(\mathrm{H} 5)$ & 0.164 & 0.161 & 0.058 & 2.822 & $0.005^{*}$ \\
\hline $\mathrm{PU} \rightarrow \mathrm{CTU}(\mathrm{H} 6)$ & 0.245 & 0.230 & 0.080 & 3.082 & $0.002 *$ \\
\hline $\mathrm{PEOU} \rightarrow \mathrm{CTU}(\mathrm{H} 7)$ & 0.107 & 0.105 & 0.035 & 3.033 & $0.003^{*}$ \\
\hline $\mathrm{KT} \rightarrow \mathrm{CTU}(\mathrm{H} 8)$ & 0.297 & 0.296 & 0.082 & 3.614 & $0.000 *$ \\
\hline $\mathrm{KOM} \rightarrow \mathrm{CTU}(\mathrm{H9})$ & 0.315 & 0.323 & 0.078 & 4.045 & $0.000 *$ \\
\hline $\mathrm{KT} \rightarrow \mathrm{PU} \rightarrow \mathrm{CTU}(\mathrm{H} 10)$ & 0.058 & 0.056 & 0.034 & 1.722 & $0.086^{* *}$ \\
\hline $\mathrm{KOM} \rightarrow \mathrm{PEOU} \rightarrow \mathrm{CTU}(\mathrm{H} 11)$ & 0.075 & 0.071 & 0.028 & 2.618 & $0.009 *$ \\
\hline $\mathrm{KT} \rightarrow \mathrm{PEOU} \rightarrow \mathrm{CTU}$ & 0.025 & 0.023 & 0.014 & 1.803 & $0.072^{* *}$ \\
\hline $\mathrm{KOM} \rightarrow \mathrm{PU} \rightarrow \mathrm{CTU}$ & 0.131 & 0.131 & 0.048 & 2.713 & $0.007^{*}$ \\
\hline
\end{tabular}

Note: *: Significant/Accepted

**: Rejected

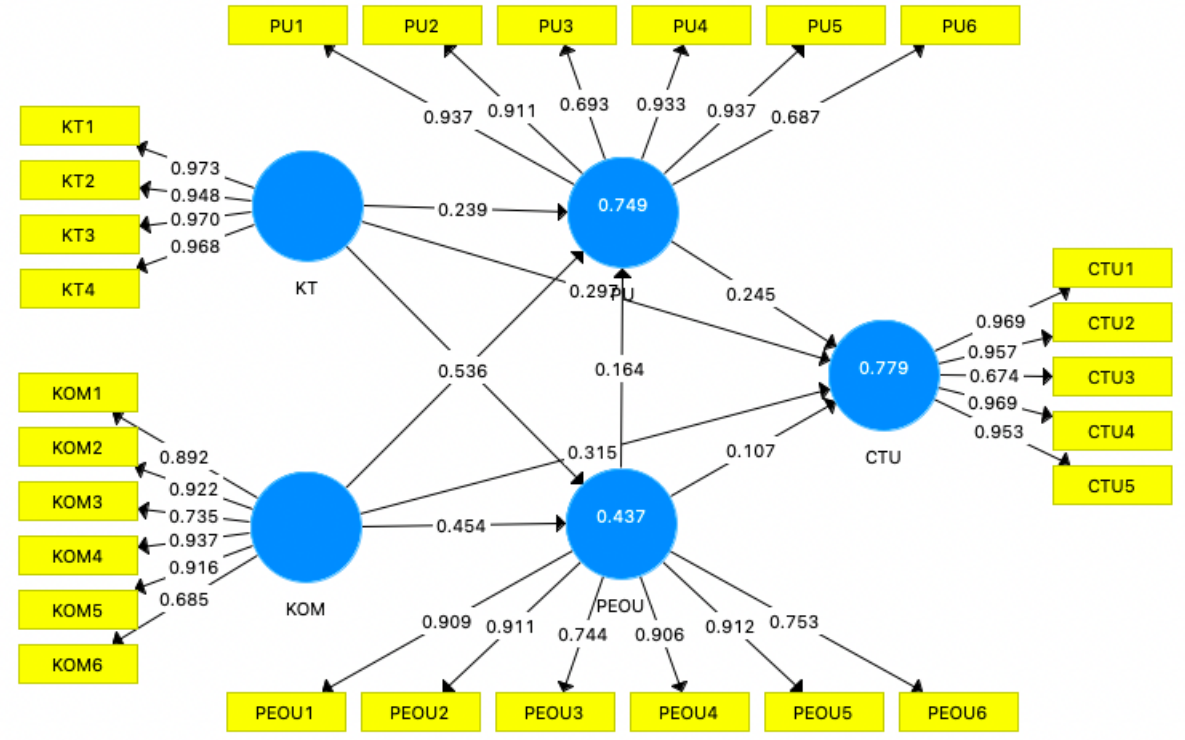

Figure 1.

Full Model Path Diagram

The data are shown in table 7 and figure 1, showing the significance and a good model in this study. The hypothesis proposed from $\mathrm{Hl}$ to $\mathrm{H} 9$ and $\mathrm{HIl}$ have good significance and are accepted. While H10 has insignificant results and it is rejected. 


\section{Discussion}

The results of this study are relevant and support several previous studies. Technological Complexity (KT) and Compatibility (KOM) as external factors in TAM theory have a significant effect on perceived usefulness (PU), perceived ease of use (PEOU), and continuance to use (CTU). Technological complexity (KT) is the level of innovation of a technology or system that is perceived as relatively difficult to understand and use, where the more complex the technological innovation, the lower level of acceptance. The study result proves that KT has a significant and positive effect on perceived usefulness (PU). This means that $\mathrm{H} 1$ is accepted. This finding is relevant and supports previous studies (Somang, Kevin, and Miyoung, 2019; Chin and Lin, 2015), which stated that technological complexity variables affect perceived usefulness (PU). It can be concluded in this study, and It was found that the level of complexity of green smart port technology (on automation equipment and digital-based operational systems in TTL) affects customers' perception of the benefits of the green and smart port concept. Technological complexity (KT) was also found to have a positive effect on perceived ease of use (PEOU). This means that $\mathrm{H} 2$ is accepted. It can be said that TTL's Customers perceive the level of innovation in green smart port technology to be easy to use or implement. This finding is also relevant and supports previous studies (Somang, Kevin and Miyoung, 2019; Chin and Lin, 2015; B.A Akinnuwesi, 2016), which stated that KT had a significant effect on PEOU.

Furthermore, this study also found that technological complexity (KT) directly and significantly affects a continuance to use (CTU). This means that $\mathrm{H} 8$ is accepted. This finding is relevant and supports research conducted by (Mndzebele, 2013; Chin and Lin, 2015), which states that KT or complexity directly affects continuance to use. However, this finding is irrelevant and does not support the previous finding (B.A Akinnuwesi, 2016), which states that complexity does not directly affect continuance to use.

Compatibility (KOM) is the degree of consistency between the new technology and customer needs, daily life routines, experiences, and values. Compatibility is also related to individual lifestyles and technology (Rogers in (Mazhar, 2014)). The study results found that KOM had a significant and positive effect on perceived usefulness (PU). This means that $\mathrm{H} 3$ is accepted. This finding is relevant and supports previous studies (Somang, Kevin and Miyoung, 2019; Di Pietro ef al., 2015; Chin and Lin, 2015; Shakrokh, 2019), which stated that compatibility had a significant and positive effect on PU. It can be concluded in this study that the level of conformity of green and smart port technology (automation equipment and digital-based operational systems) in TTL to customer needs is perceived as appropriate and useful.

Furthermore, this study also found that compatibility had a significant and positive effect on perceived ease of use (PEOU). This means that $\mathrm{H} 4$ is accepted. This result is relevant and supports 


\section{Reka Yusmara Mardiputra \\ Kusuma Ratnawati \\ Ananda Sabil H}

previous studies (Chin and Lin, 2015; Shakrokh, 2019), which stated that compatibility had a significant and positive effect on PEOU. It can be said that the green and smart port concept implemented by TTL is perceived to be in accordance with customer needs and easy to use. Furthermore, this study found that compatibility also directly affects a continuance to use (CTU). This means that $\mathrm{H} 9$ is accepted. It can be concluded that the level of conformity of the green and smart port concept (automation equipment and digital-based operational system) is implemented by TTL to the needs and values expected by customers.

Perceived usefulness (PU) and Perceived ease of use (PEOU) as internal factors in TAM theory in this study function as endogenous and exogenous variables. As an endogenous variable, PU is influenced by KT and KOM. Meanwhile, as exogenous variables, PU and PEOU affect continuance to use (CTU). The results of this study indicate that PEOU has a significant effect on PU. In comparison, PU and PEOU have a significant and positive effect on the CTU concept of the green and smart port. This means that $\mathrm{H} 5, \mathrm{H} 6$, and $\mathrm{H} 7$ are accepted. It can be concluded that the customer's perception of the benefits of the green and smart port concept implemented by TTL is affected by the ease of use of the green and the smart port concept itself. Then, the sustainability of the GSP concept in TTL (automation equipment and digital-based operational systems) is significantly and positively influenced by PU and PEOU. Intention to use the GSP concept sustainably, depending on how useful and easy to use the GSP technology or system is for the customer. This finding is relevant and supports several previous studies (Di Pietro et al., 2015; Lisha et al., 2017; Weng et al., 2017; Wu and Chen, 2016; Cheng Y.M., 2015; Ashfaq et al., 2020; Somang, Kevin, and Miyoung, 2019; Kordina et al., 2019; Choi and Park, 2015; Taufik and Hanafiah, 2019).

This study also tested the hypothesis that KT has an indirect effect on a continuance to use (CTU) and KOM has an indirect effect on a continuance to use (CTU). The study results found that technological complexity has a direct and significant effect on a continuance to use. Meanwhile, $\mathrm{KT} \rightarrow \mathrm{PU} \rightarrow \mathrm{CTU}$ and $\mathrm{KT} \rightarrow \mathrm{PEOU}) \mathrm{CTU}$ ) had no significant indirect effect. This means that $\mathrm{H} 10$ is rejected. Compatibility (KOM) was found to have a direct and significant effect on a continuance to use. Furthermore, $\mathrm{KOM} \rightarrow \mathrm{PEOU} \rightarrow \mathrm{CTU}$ and $\mathrm{KOM} \rightarrow \mathrm{PU} \rightarrow \mathrm{CTU}$ were found to have a significant indirect effect. This means that $\mathrm{H} 11$ is accepted.

\section{CONCLUSION}

Research on the concept of green and smart port (GSP) at Terminal Teluk Lamong (TTL) is the first in Indonesia. Comprehensive GSP implementation in Indonesia is only available at Teluk Lamong Terminal, Pelindo 3 group, Surabaya. The adoption of smart port technology and green port policy in this study uses the Extended TAM Theory, which places perceived usefulness (PU) and 
perceived ease of use (PEOU) variables on the continuance intention to use (CTU) GSP by adding technological complexity (KT) and compatibility (KOM) as external factors.

The results of this study indicate that technological complexity (KT) and compatibility (KOM) have a significant effect on the continuance to use (CTU) green and smart concepts. The study result proves level of complexity of a technology or system can affect a person's attitude in using new technology or system. Likewise, with compatibility, this study states that customer's needs can affect their attitude in using new technology or system.

In theory, this study has implications for the enrichment and extended of TAM theory, where the sustainability of the green and smart port concept at TelukLamong Terminal is not only significantly influenced by perceived usefulness (PU) and perceived ease of use (PEOU). Technological complexity (KT) and compatibility (KOM) have also been shown to have a significant effect on the sustainability of the green smart port concept. The complexity of automation equipment and ICT-based operational systems is an important factor that customers consider to continue using the green and smart port concept.

The results of this study also have implications for the management of Teluk Lamong Terminal to determine the right marketing strategy for customers, related to the green and smart port concepts that are implemented. Based on the research results, TTL management must consider the complexity and compatibility of a technology or system to be developed. In addition, the results shown in this study can be the main reference in the development of green and smart ports in Indonesia for the next step ahead.

This study was conducted at Terminal TelukLamong (TTL), Surabaya, East Java, in Indonesia. TTL is the first and one only green and smart port in Indonesia. Thus, this study cannot compare the concept of green and smart ports at ports or other terminals in Indonesia. The research results are very subjective, only based on a limited object of research, namely in TelukLamong Terminal. In addition, the respondents in this study, especially international shipping companies, researchers could not reach the owners of shipping companies. This is because almost all principals of international shipping companies are outside Indonesia. There is a government policy that requires international shipping companies to cooperate with local agent companies in Indonesia.

In the future, it will be better if there is more research related to the concept of green and smart ports in Indonesia and can provide comparisons to other terminals that implement GSP. Even if it does not exist yet, future research can examine other ports in Europe, America, or other countries that have implemented the concept of Green and Smart Port while at the same time reaching respondents who are company owners 
Reka Yusmara Mardiputra

Kusuma Ratnawati

Ananda Sabil H

\section{REFERENCES}

Ashfaq, M., Yun, J., Yu, S. and Loureiro, S.M. 2020. Chatbot: Modeling The Determinants Of Users' Satisfaction And Continuance Intention Of Al-Powered Service Agents. Journal Telematics and Informatic, 54.

Cheng Y.M., 2015. Towards An Understanding Of The Factors Affecting M-Learning Acceptance: Roles Of Technological Characteristics And Compatibility. Journal Asia Pacific Management Review, 20: 109-119.

Chin, J. and Lin, S. 2015. Investigating Users' Perspectives in Building Energy Management System with an extension of Technology Acceptance Model: A Case Study in Indonesian Manufacturing Companies. Journal Procedia Computer Science, 72: 31-39.

Choi, J.H. and Park, J.W., 2015. A Study on Factors Influencing 'Cyberairport' Usage Intention: An Incheon International Airport Case Study. Journal of Air Transport Management, 42: 21-26.

Hamid, A.A., Razak, F.Z.A., Bakar, A.A. and Abdullah, W.S.W. 2016. The Effects of Perceived Usefulness And Perceived Ease Of Use On Continuance Intention To Use E-Government. Procedia Economics and Finance, 35: 644-649.

Ho, J.C., WU, C.G., Lee, C.S. and T. Pham, T.T. 2020. Factors Affecting The Behavioral Intention to Adopt Mobile Banking: An International Comparison. Journal Technology in Society.

Mndzebele, N. 2013. The Effects of Relative Advantage, Compatibility and Complexity in the Adoption of EC in the Hotel Industry. International Journal of Computer and Communication Engineering, 2(4).

Di Pietro, L., Mugion, R.G., Mattia, G., Renzi, M.F. and Toni, M. 2015. The Integrated Model on Mobile Payment Acceptance (IMMPA): An Empirical Application to Public Transport. Journal Transportation Research Part, 56: 463-479.

Shakrokh, N. 2019. Factors Driving The Adoption of Smart Home Technology: An Empirical Assessment. Journal Telematics and Informatics, 45.

Somang, M., Kevin, K.F.S. and Miyoung, J. 2019. Consumer Adoption of The Uber Mobile Application: Insights From Diffusion of Innovation Theory And Technology Acceptance Model. Journal of Travel \& Tourism Marketing.

Taufik, N. and Hanafiah, M. 2019. Airport Passengers' Adoption Behaviour Towards Self-Check-In Kiosk Services: The Roles of Perceived Ease of Use, Perceived Usefulness And Need For Human Interaction. Journal Heliyon, 5. 
Weng, G.S., Zailani, S., Iranmanesh, M. and Hyun, S.S. 2017. Mobile taxi booking application service's continuance usage intention by users. Journal Transportation Research Part D 57: 207-216.

WU, B. and Chen, X. 2016. Continuance Intention to Use MOOCs: Integrating the Technology Acceptance Model (TAM) and Task Technology Fit (TTF) Model. Journal Computers in Human Behavior, 67: 221-232. 